\title{
Changes in the Mountain Farming of France: An Analysis of the Relationship between Farm Management and Policy
}

\section{ICHIKAWA Yasuo}

Geoenvironmental Sciences, Graduate School of Life and Environmental Sciences, University of Tsukuba; Tsukuba 305-572, Japan. E-mail: y.ichikawa999@gmail.com

Received February 18, 2013; Accepted August 12, 2013

\begin{abstract}
The objective of this study is to clarify the changes of agriculture in mountainous regions under the Common Agricaltural Policy (CAP) by focusing on the relationship between farm management and agricultural policy in the mountainous regions of France. In particular, a composition of income from subsidies that accounted for the total agricultural income and an investigation on the perspectives of farm households were emphasized. Since the 1960s, structural policy has differentiated between dairy husbandry management and other Mézenc operations, decreased the agricultural population, increased the number of corporation management companies, and increased productivity by agricultural production engineering and the breed improvement of livestock and grain. Meanwhile, production control policy promoted management differentiation between dairy farmers of Mézenc and diversified management types by preferential measures for beef cattle and sheep. As for agricultural income, it was clarified that the dependence of beef cattle farmers and farmers of mixed sheep on subsidies was high because of payment for the number of livestock and because dairy farmers who could not receive payment connected directly to production were disadvantaged in receiving a subsidy. However, it was clarified that cross-compliance (environment compliance rules) for subsidy requirements increased the burden of farm households and, as a result, decreased the motivation for farming operations; hence, there exists a backlash against the system and the government.
\end{abstract}

Key words mountain farming, environmental policy, cross-compliance, farm management, France

\section{Introduction}

The agricultural structure in developed countries has been significantly transformed consequent to increasing global trade liberalization and the adoption of a free market economy. Agricultural production in developed countries, which requires high labor and production costs, needs government protection and support owing to the cost competition prevailing in the global agricultural produce markets, and hence, countries have taken various political measures to sustain their domestic agricultural industry. Since the implementation of the Common Agricultural Policy (CAP) by the European Economic Community (EEC) in 1962 through the current EU (European Union), agriculture and rural areas in Europe have been particularly protected. Consequently, the highest expenditure has been on the agriculture and rural areas' category and significant funds have been invested in the European agricultural industry.

Protection and support for agriculture through policies are key conditions for regulating agricultural production and the structure of agriculture and rural areas. Agricultural policies in developed countries protect agricultural activities by price supports for specific agricultural produce and livestock, export subsidies, and direct grants to the income of farm households. It can be said that under the influence of these policies, farmers have altered the kinds of cultivated crops, livestock, and production volume, and have repeatedly changed the management type depending on the current policy. Therefore, in order to identify the changes in agriculture in developed countries, it is important to focus on changes in farm management resulting from the policy developments and to analyze the relationship between policy and farm management.

However, in the existing literature on agriculture and rural areas, the viewpoints on analyzing the changing relationship between policy and farm management have not typically been considered important factors. This study focuses on the relation between policy and agriculture change and clarifies the change of agriculture in the mountainous regions of France after the inauguration of the CAP. 


\section{Agricultural Policy Research}

In agricultural policy research in Europe, a great number of studies have been conducted on globalization and the reforms of the CAP since the 1990s. Studies have shown that the CAP of the EU was developed based on the new free market economy in the last half of the 1980s, and it has been clarified that the ideal decision-making policy conditions were formed under the strong influence of international rule by the World Trade Organization (WTO) (Potter and Tilzey 2005). In particular, since the 1990s, the EU emphasized neomercantilism for economic growth, which includes the protection of agricultural production and export expansion (Râmniceanu and Ackrill 2007). Neomercantilism in the EU is based on exporting surplus agricultural produce resulting from the protection of agricultural production to the third world at a low price, and protecting the agricultural produce market links to the EU by pressurizing agriculture in the third world (Devienne et al. 2005).

As the means to justify the apparent contradiction of such agricultural protection and trade liberalization, "multifunctional agriculture" was introduced on the international negotiation stage, and this concept has drawn strong attention in the geographic and agricultural policy research on agricultural economics. Multifunctional agriculture is a political measure that pays grants as nominal external economies and protects agriculture without infringing the international rules of the WTO, which promotes trade liberalization (Massot-Marti 2003). Research on multifunctional agriculture has been conducted from diversified perspectives, including multifunction of pasture from the standpoint of feeding the domestic herbivore (Huyghe 2008); regional differences of budget allocation related to the multifunctional agriculture of newly acceding countries because of EU expansion (Râmniceanu and Ackrill 2007); critical consideration for the concept of multifunction, where its definition differs depending on the country (Perraud 2003); and issues concerning the homogenization of agriculture and rural areas caused by multifunctional agriculture (Bazin 2003). Korenaga (1998) statistically analyzed the regional differences of mountain farming in France in terms of demographics, farmland use, and agricultural production type. Korenaga (1998) observed that agriculture in Massif des Vosges has been supported by its proximity to urban areas, opportunities for farmers to have side jobs, and environmental policy, and pointed out the importance in the Alps of promoting high value-added types of agricultural produce and the system of using meadows by elevation band.
Ishii (1998) focused on direct income compensation in extensive husbandry in the Morvan and found that it was introduced to promote fairness for dairy and grain. In addition, Ishii (1998) pointed out that this provided an incentive to prevent insufficient farmland management as well as a surplus of provisions and farmland sustainability with low productivity.

However, as Wilson (2009) pointed out, policy research related to current multifunctional agriculture lacks the viewpoints of relationship between policy and actual farm management. Likewise, Sakuyama (2006) considered it problematic to emphasize the heightening of people's expectations from agriculture and rural areas by multifunctional agriculture and accentuated the need to define a specific role for regional farmers and farmers' organizations that are multifunctional providers (Sakuyama 2006). Moreover, because multifunctional agriculture and its policy has become more important, the main target of the CAP has changed from supranational markets to national, regional, and local markets, and the local level (Charvet 2009; Clark 2006). Above all, since the expectations of external economies for agriculture and rural areas are aimed at mountainous regions and less favoured areas where natural and cultural landscapes are conserved and extensive and various agricultural types exist, it is necessary to clarify the impact of policy on agriculture in these regions (McCarthy 2005).

As mentioned above, it is necessary to study the relationship between policy development on a macro level and its regional impact on the local level in order to develop a new policy that incorporates trade liberalization. It is also important to clarify the influence of specific policies related to multifunctional agriculture on farm management by examining specific cases. In order to solve these issues, it is essential to analyze the management transition of individual farm households over time and constitutionally clarify the relationship between the transition of farm management and the development of agricultural policy.

\section{Objectives and Methods}

The objective of this study is to clarify the changes of agriculture in mountainous regions under the CAP by focusing on the relationship between farm management and agricultural policy in the mountainous regions of France.

In this article, to analyze the agricultural characteristics of mountainous regions in France, this study focuses on the management transition of individual farm house- 
holds. The dynamic state of farm management in mountainous regions is explained not only by the social and economic background, but also by the policy transition, the grants available and the selections and actions that farm households make and take in their own situation, and upon which their management transition must be focused.

Since the inauguration of the CAP in 1962 is considered a trigger for the management transition of farm households, the shift in management from the 1960s to 2011 is examined. In addition, to analyze the management transition of farm households, the following data are used, and changes are examined from the viewpoint of the decision making of farmers and the impact of policies: management type of farm households, labor force composition, kinds of livestock, and farmland change ${ }^{1}$.

Furthermore, in order to analyze the impact of policies on the current management of individual farm households more clearly, this study focuses on the composition of grants by the kinds of income of each farm household. In addition, the viewpoints of farmers in relation to these policies and management are used as data. Changes in mountain farming in France are analyzed through examination of the relationships between these policies and farm management over time by focusing on the behavior of individual management.

The study procedure is as follows. First, the differences in agricultural conditions by mountainous region are clarified, and the target regions of this study are selected. Past research and material from the French government are utilized to clarify policy transition in both France and
Europe, and reveal how the transition of these policies affected to mountain farming.

Second, regional transitions after the inauguration of the CAP are examined based on regional historical materials collected through field study, research theses, and the Agriculture and Forestry Census. In addition, for the management transition of the target regions after the inauguration of the CAP, example farm households are selected from each type of management, the details of the management trends are investigated, and their characteristics are clarified. Based on the above, the management transitions of all the investigated farm households are analyzed over time and the region-wide management types and agricultural transitions are discussed.

Finally, by focusing on how the management of the investigated farm households and agriculture policy are related, the impact of policy on management is examined. Based on the proportion of agricultural income from grants of farm households, an analysis is conducted. Through summarizing the findings, the changes in mountain farming in France are revealed.

Massif Central is a large mountainous area that includes four Régions. Auvergne which is located in the center of Massif Central is one of the leading mountainous husbandry areas in France and the ratio of less favoured areas accounting for the région is high. In Auvergne, farm households of cattle breeding accounts for approximately $70 \%$ of the total and the rest are farm households of sheep breeding and farm households of crop farming. Of all the four departments which are included in the same région, Cantal and Haute-Loire where over 95\% of com-

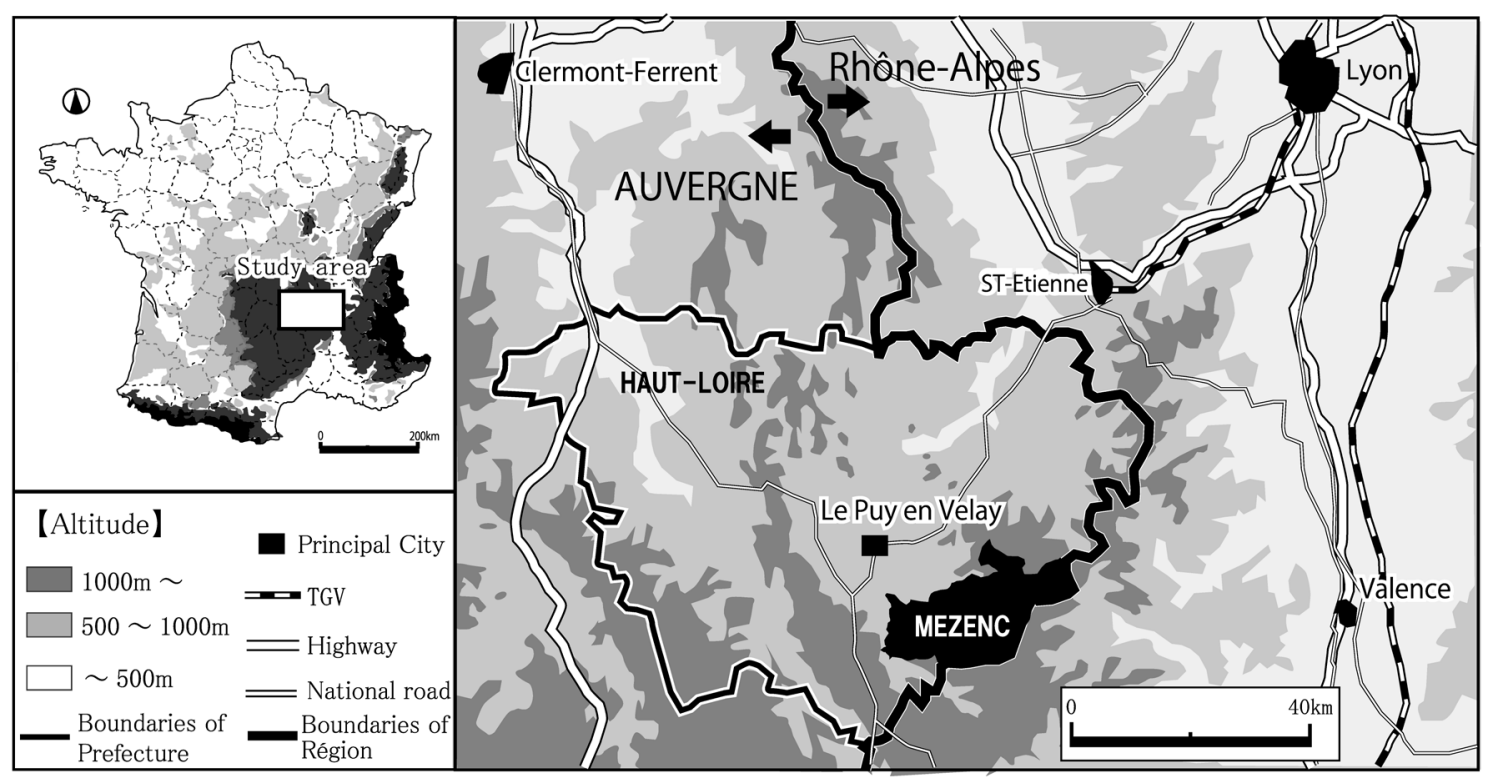

Figure 1. Study area.

Source: Topographical maps of IGN France. 
munes are located in mountainous regions have stronger agricultural characteristics. In Cantal, cattle breeding management accounts for over $90 \%$ and there is no crop farming. In addition, the altitude of Haute-Loire is the highest in Auvergne, the climate condition is severe, and the average farmland area is the least: it is the most difficult regions with such unfavorable conditions to do farm management in Massif Central. As the above mentioned, it can be said that Haute-Loire is appropriated to analyze farm management and its changes of mountainous farm households in a region with unfavorable conditions from various perspectives.

In this study, Mézenc located in the southeast of HauteLoire is set as a study area (Figure 1). Mézenc is located in a high altitude area in Haute-Loire and strongly depends on extensive husbandry centering on cattle livestock. In the field study, a hearing investigation was held on cur- rent management, management transitions, and relationship to policies using a survey form for each farm. Each farm household provided details of its management based on its own record of income and expenses.

\section{Agricultural Policy and Rural Areas in Mountainous Regions in France}

\section{Development of agricultural policy and rural areas}

The development of agricultural policy and rural areas in the mountainous regions of France can be divided into two main periods: (1) before the common agricultural policy (CAP) by the EEC and (2) after the CAP. The reason for the division is the supranational intervention in the prices of agricultural produce as a result of the CAP and the initiation of protection for trade within the region. In this article, the period from the early 19th

Table 1. Policy transition over mountain farming of France

\begin{tabular}{|c|c|c|c|c|}
\hline & Year & France & Europe & Policy \\
\hline \multirow{3}{*}{ Forest Policy Period } & 1827 & Forestry Code & & \multirow{3}{*}{ Forest Protect } \\
\hline & 1913 & French Alps Economic Association & & \\
\hline & 1956 & Congress of Dairy Producers in Mountains & & \\
\hline \multirow{8}{*}{$\begin{array}{l}\text { Production Expansion } \\
\text { Agricultural Policy } \\
\text { Period }\end{array}$} & \multirow{3}{*}{ 1961-1962 } & $\begin{array}{l}\text { French Agricultural Basic Act Zoning Range } \\
\text { of Mountain Region }\end{array}$ & \multirow{3}{*}{ Common Agricultural Policy } & \multirow{8}{*}{ Scale Expansion } \\
\hline & & $\begin{array}{l}\text { Common Management Agricultural Group } \\
\text { (GAEC) }\end{array}$ & & \\
\hline & & $\begin{array}{l}\text { Life Annuity to Encourage Farm Retirement } \\
\text { (IVD) }\end{array}$ & & \\
\hline & 1966 & Regrouping Agricultural Land & Mansholt Plan & \\
\hline & 1972 & $\begin{array}{l}\text { Special Compensation for Mountainous } \\
\text { Regions (ICHN) }\end{array}$ & & \\
\hline & 1973 & System to Promote Young Farmers & & \\
\hline & 1975 & Expansion of Less Favoured Areas & & \\
\hline & 1980 & Reform of French Agricultural Basic Act & $\begin{array}{l}\text { Financial Incentive for Beef } \\
\text { Cattle and Sheep }\end{array}$ & \\
\hline \multirow{4}{*}{$\begin{array}{l}\text { Production Control Agri- } \\
\text { cultural Policy Period }\end{array}$} & 1984 & & Milk Quota System & \multirow{6}{*}{$\begin{array}{l}\text { Decoupling Reduc- } \\
\text { tion of Agricul- } \\
\text { tural Protection }\end{array}$} \\
\hline & 1985 & $\begin{array}{l}\text { Exploitation Agricole à Responsabilité Limitée } \\
\text { (EARL) }\end{array}$ & $\begin{array}{l}\text { Environmentally Sensitive } \\
\text { Areas (ESA) }\end{array}$ & \\
\hline & 1992 & $\begin{array}{l}\text { Environmental Policy. Incentive for Grassland } \\
\quad(\mathrm{PH})\end{array}$ & $\begin{array}{l}\text { CAP reform. Direct Payment } \\
\text { System }\end{array}$ & \\
\hline & 1999 & $\begin{array}{l}\text { Reform of French Agricultural Basic Act. } \\
\text { Contrat Territorial d'Exploitation (CTE) }\end{array}$ & $\begin{array}{l}\text { Agenda } 2000 \text { Introduction } \\
\text { of Cross-Compliance }\end{array}$ & \\
\hline \multirow{2}{*}{$\begin{array}{l}\text { Environmentally Focused } \\
\text { Agricultural Policy } \\
\text { Period }\end{array}$} & 2005 & & $\begin{array}{l}\text { Expansion of } \\
\text { Cross-Compliance }\end{array}$ & \\
\hline & 2009 & Expansion of Subsidies for Sheep Breeding & & \\
\hline
\end{tabular}

Source: Gerbaux (1994), Martin et Novaria (1991) and Loyat et Petit (2008). 
century (before the inauguration of the CAP) to 1961 is defined as the "forests policy period." In this period, the main target of the policy is not farm management but forests. The period after the inauguration of the CAP is divided into three periods, as described below, based on optimal agricultural support from government policy. The first period is from 1962 to 1983 , the year before the inauguration of the policy to control agricultural production. This first period is defined as the "production expansion agricultural policy period." During this time, the Agricultural Basic Act (Loi d'Orientation Agricole) was enacted to expand production and scale. The second period is from 1984 to 2002. In 1984, the milk quota allocation system was implemented to control agricultural production. This second period is defined as the "production control agricultural policy period." The third period, from 2003 onward, is defined as the "environmentally focused agricultural policy period." In 2003, grant payments for the environment were reinforced by the reform of the CAP and the introduction of a direct payment system. The following sections describe the development of agricultural policy in the rural areas of France with a focus on mountainous regions (Table 1).

\section{Period before the Common Agricultural Policy}

National institutes and official powers began implementing policies for mountainous regions in France in the 19th century (Gerbaux 1994). In the period that followed the early modern period in France, population expansion increased pressure in the margins of rural areas, resulting in deforestation and the expansion of farmland (Korenaga 1998). In the second empire, Napoleon III sensed the potential crisis resulting from the destruction of forests and enacted the "Forestry Code (Le Code Forestier)" in 1827 to control the national forests and the system of communal forests. The protective policy of forests continued even after the third Republican period began in the late 19th century, expanding to include farmers residing in mountainous regions. Protective policy of forests was continued even after the third republican period began in the late 19th century and expanded to include farmers residing in mountainous regions as a protection target. In particular, the establishment of the "French Alps Economic Association (Société d'Économie Alpestre Française)" responsible for the promotion of agriculture in the Alpine area, in 1913 was a symbolic event and it became a basis for the organization of the later "Economic Federation of French Mountainous Regions (Fédération Française d'Économie Montagnarde)" comprising all of the French mountainous regions. As a result, it promoted the introduction of agricultural technology in mountainous rural areas and the development and extension of farm management.

Agricultural problems in the mountainous regions of France came to the fore after World War II. In particular, securing an income from dairy farming, which was a key industry in the mountainous regions, operating in unfavorable production conditions became a significant issue. To address these issues, the "Congress of Mountain Dairy Producers (Congrés des Producteurs de Lait en Montagne)" was organized in 1956. Dairy producers claimed that husbandry conditions in the mountains were unfavorable, based on natural conditions. Stabilized price of milk would help to alleviate the unfavorable conditions and enable farmers to introduce technology and develop dairy farming in the mountains. However, the nationwide federation of dairy producers did not completely accept this proposal (Korenaga 1998). The background of this situation was a delay in the development of a law protecting agriculture in the mountainous regions of France. In contrast, neighboring countries had already promoted laws to develop and improve mountain farming after World War II. For example, the Mountain Law was enacted in 1951 in Italy, laws were developed in 1950 in Austria, and protective laws for hill farming were established in 1946 in the United Kingdom (Chevallier 1989). The delay in developing such laws in France was because the centralized state regime regarded the French nation as one area and thus did not recognize the scattered mountainous regions as independent areas (Broggio 1992).

\section{Production expansion agricultural policy period (1961-1983)}

Structural reform In 1961, mountain farming was introduced in the agricultural policy of France for the first time. In France in the early 1960s, the French Agricultural Basic Act (1961-1962) was developed with the aim of agricultural structural reform by expanding the scale of agriculture. The intention of the Act was to help maintain the resident population in mountainous regions, and mountain farming was ascribed a regional designation for the first time. The zoning range of this Agricultural Basic Act included the mountainous regions of the Pyrenees, the southern part of Massif Central, the Alps, Jura, and Vosges. However, agriculture in the mountainous regions during the structural reform period was not a primary target of the agricultural policy in France. Therefore, although the rural areas of these mountainous regions were designated within the zoning range, there was no fullscale policy tailored specifically for mountainous regions. 
The reasons for this lay in the characteristics of the system of structural reform as described in the French Agricultural Basic Act.

The fundamental principles of the French Agricultural Basic Act were to eliminate the regional imbalance among French rural areas, which were characterized by complicated and diverse agricultural land conditions, and establish an economic and social state of balance. To redress regional imbalances and achieve "economic equilibrium," the following structural measures were applied as solutions: (1) the liquidation of farmland, (2) the largescale incorporation of farm management, and (3) the promotion of farm retirement for elderly people. With regard to the liquidation of farmland, the Development Corporation of Rural Community Land (SAFER: Société d'Aménagement Foncier et d'Établissement Rural), responsible for acquiring and reselling farmland, was established and farmland that was restricted by land owners in the past was "released (liberation)" and leased or sold to farmers wishing to expand the scale of their operations. To reduce the size of the agricultural workforce and to select and integrate management, "Life annuity to encourage farm retirement" (IVD: Indemite Viagère de Départ) was introduced in the Agricultural Basic Act in order to offer annuity compensation and early farm retirement for elderly farmers. IVD requires that land be sold or leased to young farmers, irrespective of whether they are family members, and that these farmers must have contributed to the expansion of a young management class and promoted farmland liquidation in a significant manner. As a result, from the early 1960s to the 1990s, there was a change in the ownership of $35 \%$ of the total farmland (11,440K ha) in France (Servolin 1989).

Formation of measures for mountain farming Measures for mountain farming in France have been fully developed since the 1970 s, mainly initiated by a comprehensive development of rural areas by the French government. This was driven by the "Interministerial Delegation for Territorial Planning and Regional Attractiveness" (DATAR: Délégation Interministérielle à l'Aménagement du Territoire et à l'Attractivité Régionale), whose purpose was to redress the remarkable economic imbalance between mountainous and other regions with respect to infrastructure development, agricultural reform, tourism promotion, and industrialization of regional produce. The main targets of DATAR were Massif Central (Auvergne and Limousin), an area with an aging farming population and unfavorable natural farming conditions, and Bretagne. In addition, mountainous village development measures were implemented under the garb of "rural region innovation" (rénovation rurale).

In the background of the mountain farming policy from the late 1960 s to the 1970 s was a heightened sense of a mountain farming crisis, highlighted by the "Mansholt Plan," which was implemented with the inauguration of the CAP (Korenaga 1998). The Mansholt Plan aimed to reduce farmland by 5 million ha and the number of farmers by 5 million. The plan clarified that mountainous regions were structurally unfavorable for farming in comparison to flat regions, and this provided momentum to the expansion of the policy of mountainous regions.

\section{Production control agricultural policy period (1984-2002)}

Expansion of mountainous agricultural policy In the 1980s, the mountain farming policy was further expanded. The main background to this was the rise of the leftist party in France (Broggio 2002). The leftist party reinforced the intervention into the mountain village policy from the early 1980s onward, based on three principles (Servolin 1989). The first was "egalitarianism." Since the structural policy of the conservative government from the early 1960s benefitted only the wealthy class, it was identified that small-scale farmers and elderly people, to whom the existing policies did not apply, and the less favoured areas, needed support as well. The second principle was the concept of "ruralism," which emphasizes rural development. As a result of political measures that emphasized agricultural technology in structural reform since the 1960s, as well as the development of capital, productivity progressed to the point where there was a surplus of agricultural produce. Consequently, the financial cost to both the nation and the EC (European Community) increased. Reflecting on these problems, policy changeovers that focused on rural areas, including harmonization with the environment and the development of natural space, were considered essential. The third principle is the concept of "national voluntarism," which emphasizes the view that the nation must play the role of regulator in the agricultural sector, or related industries, through agricultural policy, as well as controlling surplus production or environmental load.

Intervention in the mountain farming policy by the leftist party, built on these three principles, promoted mountainous regions in terms of various aspects, including the expansion of the target range of less favoured areas, a budget increase for the special compensation for mountainous regions, and the establishment of a "mountainous regional law" in 1985. At the same time, in an 
effort to expand grants to mountainous rural areas, a decentralization policy (décentralisation) was implemented from the 1980s onward in France. The decentralization policy aimed to balance the development of national land to redress the overconcentration around Paris. This promoted regional formulation, gave local regions or peripheral areas a main role, and created the basis of the agricultural promotion policy in mountainous regions and less favoured areas from then onward.

Introduction of direct payment and the environment policy The major turning point of the CAP in the 1980s was the introduction of the "Milk Quota System" (Quota laitière) in 1984. The increase in food production required after World War II, and the EC common agricultural policy of not limiting production volumes put pressure on the finances of the EC (Servolin 1989). The situation caused a chronic excess in the production of butter and milk. As a result, the milk quota system was decided on as one possible measure of controlling production. This became a significant trigger of change to the direction of the EC's policy-from an agricultural policy of production expansion to one of production control. It was also the basis of the introduction of a direct payment system mediating the environment, which began in the 1990s. While reducing dairy production, the following were introduced from 1980 onward: "PMTVA: La Prime au Maintien du Troupeau Vaches Allaitantes," which is a financial incentive for beef cattle, and "PCO: Prime Compensatrice Ovine," which is a financial incentive for sheep $^{2}$. These incentives led to a decrease in domestic herbivores (dairy cattle), complemented by an increase in beef cattle and sheep. As a result, grazing areas have been sustained.

Subsidies for the export of agricultural produce, price intervention, and subsidies for domestic production in France were largely eliminated in the late 1990s. The government provided approximately 15 million euro in subsidies for the export of agricultural produce in 1999, which was subsequently reduced to 1.7 million euro in 2010 (Figure 2). In place of subsidies, direct payment, payments to less favoured areas, and payments for the environment increased. These payments accounted for the major part of the subsidy expense since the late 1990s. The reduction of price support for agricultural produce and the introduction of a direct payment system marked the beginning of a subsidization policy to compensate the deficits of farm managements, caused by the reduction of price support, with a grant for the environmental preservation for agriculture.

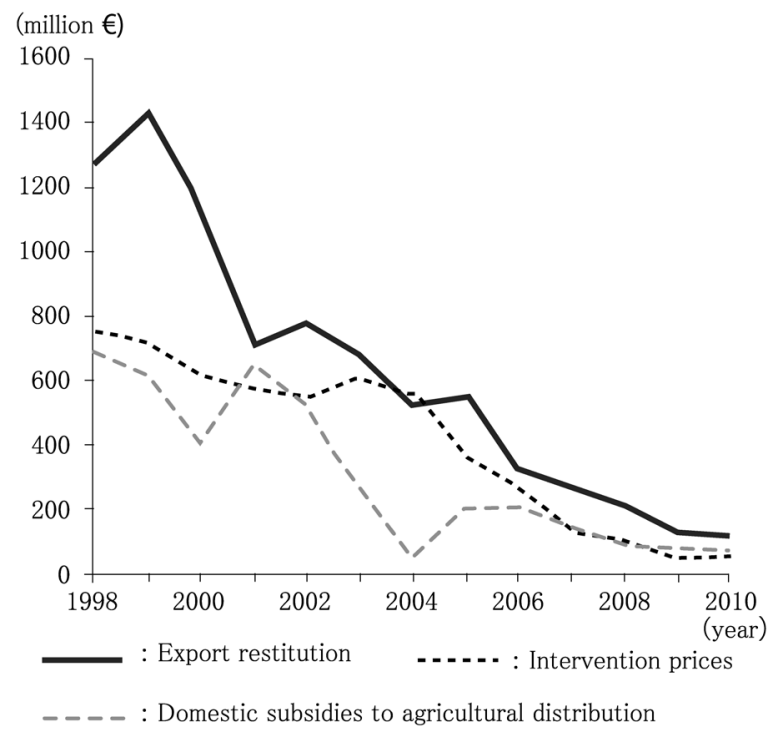

Figure 2. Transition of price supports for agricultural produce in France.

Source: Les concours publics à l'agriculture en 2010.

Environmental policy in France has made dramatic progress since the 1990s. Various environmental programs were introduced, including the "Incentive for Grassland" (Prime à l'Herbe), which is a program for maintaining extensive farmland and promoting appropriate control and subsidies for organic farm management. Furthermore, in 1999, the "CTE: Contrat Territorial d'Exploitation"3 was established, which reformed the French Agricultural Basic Act and environmental programs in which consideration for the environment is imposed on farm households through the "Contract with Administrative Organs." The formation of these environmental policies resulted from the emphasis on "multifunctional agriculture" by international institutions such as the WTO, FAO, and OECD. The idea here was that rural areas are a "non-tradable commodity" in international politics. The background to these trends was the introduction of "cross-compliance" ${ }^{4}$ as subsidy requirements for farm households in "Agenda 2000"5 in 1999 and the reform of the CAP in 2003. The introduction of crosscompliance triggered the enhancement of environmental policies after 2000 in the EU.

\section{Environmentally focused agricultural policy period (2003-present)}

The enhancement of agricultural environment protective functions by direct payments, promoted during the 1990 s, was more focused as a result of the introduction of "decoupling" (a single payment) with the reform of the CAP in 2003. Decoupling means reforming agricultural policies so that they reduce their interference with pro- 
duction decisions. This policy does not apply increases or decreases in the number of livestock and production volume of farm households to subsidies. Considering the transition of subsidies after 1991 in France, decoupling has become prominent since 2006 and accounted for $72.5 \%$ ( $€ 7.2$ billion) of agricultural subsidies in France. In contrast, payments that are directly connected to production volume drastically reduced from 2006 onward, shrinking from $€ 6.9$ billion to $€ 1$ billion between 2001 and 2011.

In 2003, the reform of the CAP included the "obligation of cross-compliance," which became a required condition for all direct payments from 2005 onward. In addition, the number of cross-compliance payments increased after 2005, and political regulations for farm management of farm households have been reinforced.

As a result of these policies, farm management in France has largely depended on subsidies; in particular, it is no longer unusual for a subsidy to be greater than agricultural income in rural areas with unfavorable conditions. Subsidies have been supported by the nation's taxpayers, which has made it essential for the nation to understand that protection for farm management that focuses on less-favoured areas has social "legitimacy" (legitimité). In this manner, multifunctional agriculture has been increasingly emphasized in policies since the 2000s.

\section{Agricultural Transition and Management Differentiation in Mézenc}

\section{Agricultural transition in Mézenc}

The original type of agriculture in Mézenc developed in the 19th century (Féminier 2000). In particular, the first agricultural cooperative association in Haute-Loire and the railroads between Le Puys and Saint-Étienne were symbolic events that significantly changed the agricultural environment for farmers in this region. The development of the transportation network and the establishment of the association enabled the distribution of local products to urban areas. In addition, a livestock and farm product show, launched in 1839 , caused farm and animal husbandry households to become more interested in better quality products. Developments such as the acquisition of AOC (Appellation d'Origine Contrôlée) in Le Puys in 1935 and the establishment of the Lentils Association of Haute-Loire have been significant for quality improvement and better-value regional farm products.

In the 1960s, Mézenc and its peripheral rural areas faced a significant turning point when various policies for agricultural modernization were initiated. Specifically, the establishment of "SAFER Auvergne," an intermediate agent for farmland leasing, buying, and selling, and the project for land improvement in Haute-Loire, were representative of policies aimed at the efficiency of agriculture. However, while cultivated land improvement in Haute-Loire was rapidly promoted in the middle of the 1960s, that in Mézenc stagnated because of a strong protest movement by local farm households. Of the rural communities in France, in Auvergne the traditional agricultural type has been passed over and it has often been mentioned as the last region of agricultural innovation and introduction of new technologies. People, especially, are very conservative in Mézenc and the progress of structural reform to modernize agriculture was slow compared to other regions. The protest movement in Mézenc continued, and the farmland improvement project has only recently been completed.

The influence of policy on structural reform became evident in Mézenc after the 1970s, when support for young farmers and the retirement of elderly farmers were promoted. Above all, the reduction in the number of farmers during the 1970s became a major turning point; moreover, the number of farms handling beef and dairy cattle drastically decreased. With the increase in the number of these retired farmers, large-scale farm households increased their scale of operation. In particular, in economically large farm households, called "professional management," the average amount of cultivated land increased from 38ha in 1975 to 65ha in 2000. In terms of the number of farm households, the number of owners of more than 50ha of land increased from 48 in 1979 to 181 in 2000 and the total land owned by them increased from 497 ha in 1979 to 1,252 ha in 2000.

Simultaneously with this expansion, more and more agricultural machinery was being introduced into farming in the 1960s. For example, 2,000 tractors were owned in Haute-Loire in 1955. This figure increased to 7,040 in 1963 and 10,800 in 1970. By 1979, there were more tractors than there were farm households in Haute-Loire (Frasse 2000). In addition, the introduction of harvesters, balers, and loading machinery for silos also increased rapidly during the 1960s and these played a major role in managing larger farms after acquiring the farmland of retired or elderly farmers. In other words, farm households that could not invest in such agricultural machinery retired or became subsistence farmers by downsizing their farms.

Considering the number of farms by type in Mézenc, the number of cattle farms has decreased, but beef cattle farms have increased and tended to be more stable. The 
Table 2. Transition of cattle breeds in Haute-Loire (1955-1997)

\begin{tabular}{|c|c|c|c|c|c|}
\hline Breed (head) Year & 1955 & 1968 & 1979 & 1988 & 1997 \\
\hline Montbéliarde, Abondance & 25,000 & 58,000 & 83,600 & 95,840 & 84,200 \\
\hline Pied-Noir & - & 11,400 & 26,160 & 28,960 & 19,300 \\
\hline Aubrac & 35,000 & 11,500 & 2,500 & \multirow{3}{*}{2,250} & \multirow{3}{*}{3,200} \\
\hline Salers & 22,000 & 12,200 & 900 & & \\
\hline Tarine & 1,000 & 3,700 & 3,700 & & \\
\hline Mézine & - & 800 & 0 & 0 & 0 \\
\hline Charolaise & - & - & - & 1,480 & 6,600 \\
\hline Limousine & - & - & - & 380 & 5,500 \\
\hline Others & 42,000 & 18,400 & 13,800 & 5,030 & 6,300 \\
\hline
\end{tabular}

-: No data

Note: Aubrac, Salers, and Tarine in 1988 and 1997 are the total of 3 breeds.

Source: AGRESTE Recensement Agricole and 100ans d'Agriculture en Haut-Loire.

Table 3. Transition of grain and farmland use in Haute-Loire (end of 19th century-2010)

1) Transition of grain

\begin{tabular}{|c|c|c|c|c|c|}
\hline \multirow{2}{*}{ Year } & \multicolumn{5}{|c|}{ Grain and Lentils (ha) } \\
\hline & Wheat & Barley & Rye & Lentils & Total grain \\
\hline 1888 & 14,122 & 24,201 & 76,112 & 1,960 & 144,899 \\
\hline 1912 & 21,830 & 24,870 & 63,200 & 2,980 & 136,476 \\
\hline 1929 & 21,810 & 15,243 & 40,940 & 2,165 & 103,583 \\
\hline 1955 & 17,451 & 10,830 & 26,135 & 3,000 & 70,529 \\
\hline 1963 & 18,000 & 12,500 & 19,500 & 2,000 & 65,400 \\
\hline 1970 & 13,416 & 14,315 & 14,583 & 1,800 & 56,725 \\
\hline 1979 & 11,935 & 16,340 & 12,313 & 900 & 51,674 \\
\hline 1988 & 10,382 & 13,250 & 5,906 & 1,000 & 42,190 \\
\hline 1998 & 12,000 & 13,000 & 3,500 & 3,814 & 36,500 \\
\hline 2010 & 13,359 & 7,495 & - & 5,200 & 32,803 \\
\hline
\end{tabular}

2) Transition of farmland

\begin{tabular}{|c|c|c|c|c|c|c|c|}
\hline \multirow[b]{2}{*}{ Year } & \multicolumn{7}{|c|}{ Non-Grain (ha) } \\
\hline & Potato & $\begin{array}{l}\text { Artificial } \\
\text { grassland }\end{array}$ & $\begin{array}{l}\text { Temporal } \\
\text { grassland }\end{array}$ & Corn & Grape & Fallow land & Total non-grain \\
\hline 1882 & 16,300 & - & - & - & 8,961 & - & - \\
\hline 1929 & 17,441 & 5,489 & 82 & 138 & 1,914 & 8,585 & 33,649 \\
\hline 1955 & 9,271 & - & - & - & 954 & - & - \\
\hline 1963 & 5,900 & 13,100 & 5,900 & 1,000 & 840 & 3,870 & 30,610 \\
\hline 1970 & 3,770 & 11,100 & 10,900 & 700 & 820 & 2,690 & 29,980 \\
\hline 1979 & 2,100 & 10,900 & 13,800 & 3,725 & 490 & 627 & 31,642 \\
\hline 1988 & 652 & 6,000 & 23,500 & 5,825 & 285 & 719 & 36,981 \\
\hline 1998 & 282 & 2,100 & 31,600 & 7,200 & 171 & 450 & 41,803 \\
\hline 2010 & 121 & 1,452 & 41,005 & 8,061 & 16 & 288 & 50,943 \\
\hline
\end{tabular}

-: No data.

Source: AGRESTE Recensement agricole and 100ans d'Agriculture en Haut-Loire. 
number of farmers of mixed sheep has not seen a significant decrease.

In Mézenc as a whole, during the decline and obsolescence of small-scale dairy farm households, large-scale dairy farmers have tended to either specialize in beef cattle operations or run multiple operations by combining sheep, dairy cattle, or beef cattle since the 1970s. As a result, diversification of farm management has also been promoted. In addition, since the 1960s, regional breeds of livestock-including Aubrac and Salers-have rapidly decreased; in contrast, non-regional breeds of lean beef cattle, such as Montbéliarde and Abondance, have increased (Table 2). Mézine, specific to Mézenc, have completely disappeared since 1979. There used to be various breeds in this region and many dairy cattle farm households reared hybrids of those breeds. However, since the 1960s, the number of breeds has decreased and farmers have tended to standardize specific breeds whose individual weights are heavy and the breeds themselves are productive.

The structural improvement policy by the CAP has also brought significant change in the use of farmland and grain cultivation in Mézenc. Table 3 indicates the transition of the use of farmland in Haute-Loire, to which Mézenc belongs, from the end of the 19th century to 2010. In 1888 , the grain cultivation area was 140,000 ha at its peak; since then, it has consistently decreased. In particular, rye-which accounted for approximately 50\% of the area of whole grain farming until the early 20th century-decreased to less than $10 \%$ in the 1990s. In contrast, the ratio of wheat and barley has increased. Although lentils continued to decrease after peaking in 1955, lentil farming has been re-evaluated and its cultivation area has increased again since the 1990s. In terms of non-grain farmland use, the area used for potatoes-a significant food source for people and livestock in rural areas-has rapidly decreased and is currently less than $1 \%$ of that in 1882. With the increase in the number of dairy cattle farms, the cultivation of corn, which can be used as livestock feed, has increased and the area of temporal grassland used for feed has expanded. As a background to this change, farming policy has promoted the discontinuance of grain cultivation because production is inferior to that of large-scale grain farms in flat areas in terms of price competition. As a result, farms have begun to specialize in dairy husbandry, where higher sales prices can be expected. Moreover, although diversified grain cultivation played a key role in the landscape composition of rural areas, the landscape has since changed to be more uniform with grassland. As a result, there has been a de- cline in specific grain breeds that can adapt to regional natural conditions.

\section{Differentiation and specialization/Multiple operation of farm households}

Figure 3 is a classification of the management transition after the 1960s with regard to the farm households investigated in Mézenc. Each farm household in Mézenc has repeatedly implemented change and differentiation in its management and each type of management transition has its own characteristics.

First, the management transition of dairy farmers has

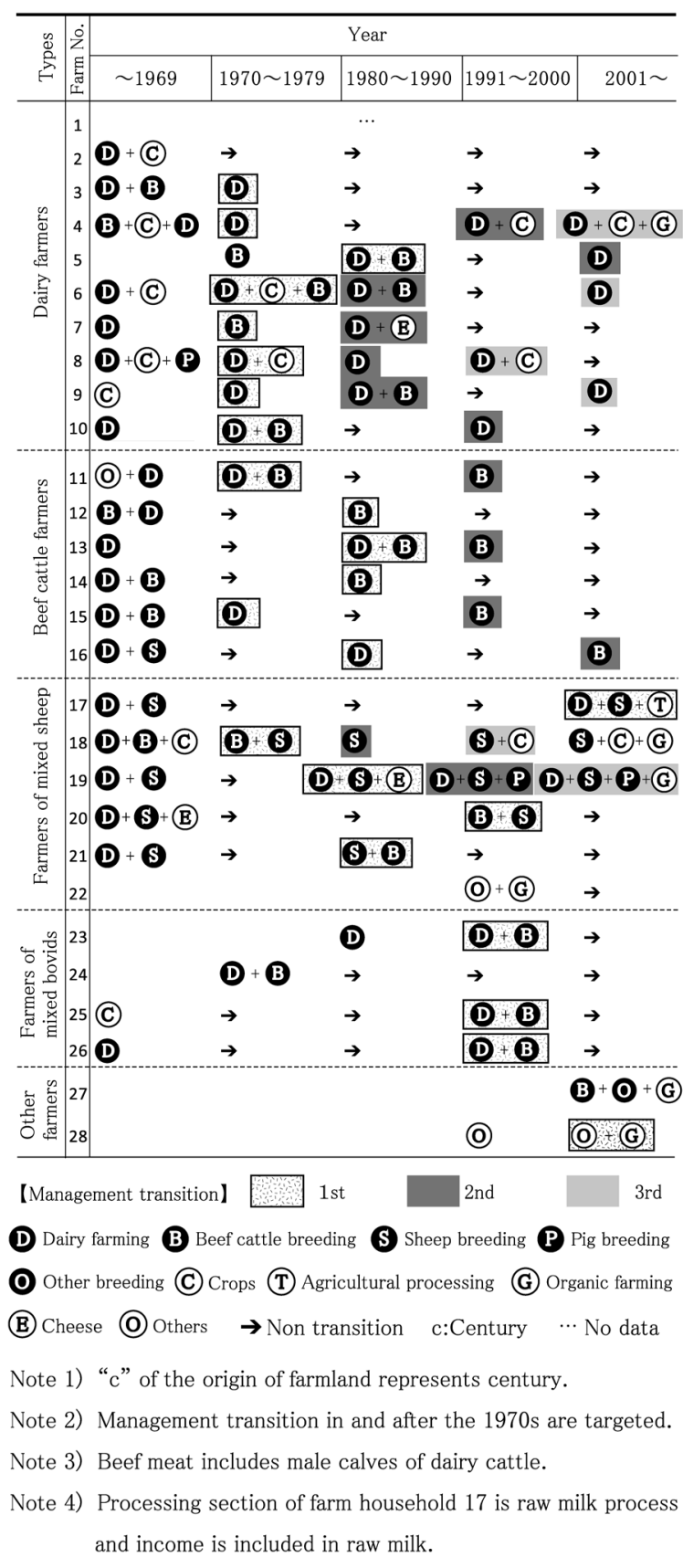

Figure 3. Management transition of farm households in Mézenc.

Source: Author's interview and account books of farmers. 
the characteristic of shifting its operation from traditional "dairy husbandry with other farming operation" to a combination of grain cultivation, beef cattle husbandry, or process food production with dairy husbandry, specialized operations for non-dairy husbandry, or dairy husbandry only. In the past, dairy farmers focused on raw milk production and operated a multiple dairy husbandry that included dairy, beef, and cheese processing as byproducts; grain production for livestock feed and sales; and swine husbandry. Differentiation and specialization of dairy farmers occurred earlier than those of other management types and seven out of nine made a change in their management in the 1970s.

With regard to the first management change of each dairy farmer, five households enhanced the ratio of dairy husbandry operations (farm households $3,4,5,8$, and 9) and three farm households introduced a beef cattle operation (farm households 6, 7, and 10). There existed two types of change-specialization in dairy husbandry and multiple operations with dairy cattle. In contrast, there were two farm households that discontinued grain cultivation (farm households 6 and 8) and specialized in dairy husbandry.

Four farm households made the second management change in the 1980s (farm households 6-9), two in the 1990s (farm households 4 and 10), and one after 2001 (farm household 5). They are classified in the following manner: farms running multiple operations by agricultural produce, such as cheese and lentils, with the purpose of adding high value (farm households 4 and 7); the remainder reinforced their specialization in dairy cattle or beef cattle operations (farm households 5, 6, 8, and 9).

With regard to dairy farms where management differentiation occurred earlier than other types, four farm households out of nine (farm households 4, 6, 8, and 9) made the third management change, which is more than the other types of change. Farm households 6 and 9 discontinued beef cattle husbandry since the 2000s and specialized in dairy husbandry. Farm households 4 and 8 have reintroduced lentil cultivation, which used to be cultivated for self-consumption, since it was revaluated by the media after the 1990s. The characteristic changes made by dairy farmers are the introduction of beef cattle after the 1980s and their specialization or return to multiple farming operations such as processing food and grain.

Next, we consider the management transition of beef cattle farmers. All farm households, with the exception of farm household 13, differentiated from multiple-farming operations by focusing on dairy husbandry. This management change occurred mainly after the 1980s. These farm households can be classified into two types: three farm households (farm households 12, 14, and 15) that have reared beef cattle since before the 1970s and three farm households (farm households 11, 13, and 16) who introduced beef cattle after the 1970s. Management that originally reared beef cattle gave up dairy husbandry in the early period as a result of the introduction of the milk quota system and attempted specialization in beef cattle (farm households 12 and 14). Farm household 15, which once shifted to a dairy husbandry operation, specialized in beef cattle since the 1980s as a result of the impasse of raw milk production.

In contrast, farm households that introduced beef cattle after the 1970s have combined dairy and beef cattle husbandry (farm households 11 and 13) or dairy cattle and sheep husbandry (farm household 16). However, they shifted to beef cattle when the initial capital investment was small. Production expansion could be expected after the 1990s because of the low price of sheep meat and limited raw milk production. The origin of farmland for beef cattle farmers is relatively new when compared to that of dairy farmers. In addition, they tend not to be restricted by land inherited from ancestors or agricultural policy and were flexible in shifting to a beef cattle operation.

Next, the management transition among farmers of multiple farming operations is examined. The original management of all farmers of mixed sheep, other than farm household 22, involved multiple husbandries with a combination of cattle and sheep. Four of these operations (farm households 17 and 19-21) introduced sheep husbandry before 1970. The management type of farmers of mixed sheep is based on technology or the know-how of sheep husbandry that has been handed down from generation to generation.

Although the process of differentiation and multiple operations of farmers of mixed sheep depend on the farm household, all of them have continued multiple operations rather than specialization. With regard to the period of management change, beef cattle husbandry was introduced between the 1970s and 1980s and after the 1990s. High-value farming and pluriactivity-such as applying organic agriculture, lentils, agricultural processing, and an accommodation service as a side business - have been selected. Preferential measures for sheep were taken after 2000. Each farm has attempted multiple operations and changing its original management type.

In contrast, in the case of farmers of mixed sheep, there have been few management changes by farmers of mixed bovids, and only three farm households have introduced beef cattle to management based on dairy husbandry 
(farm households 23, 25, and 26). These management changes were all made in the 1990s. It is considered that these farmers attempted to compensate for the income decrease caused by the limits of operation expansion due to the introduction of the milk quota system in the 1980s by including beef cattle, which is unique to corporate farms that have an abundant labor force. Farmers of mixed bovids do not introduce new operations other than those of dairy and beef cattle and the specialization and continued expansion of both operations is important. Most of their farmland is new and has been the trigger to expand their scale of operation when they are able to secure new farmland when other dairy or beef cattle farmers downsize or abandon their farms.

As previously noted, management differentiation of farm households in Mézenc is classified in terms of transition from the 1960s in Figure 4. Each farm household in Mézenc was originally a dairy farm. Management differentiation and specialization in dairy farmers and multiple operations with beef cattle occurred in the 1970s. Since the middle of the 1980s, dairy farmers have promoted high-value produce and specialized in management. This intensified dairy production in the 1990s and, as a result, they became "dairy farmers."

In contrast, farmers who downsized their dairy operations and introduced and reinforced their beef cattle operations in the 1980s and promoted specialization in beef cattle throughout the 1990s became "beef cattle farmers." With regard to dairy farmers with other operations, farmers that diversified multiple operations or introduced ag- ricultural production of high-value produce between the 1980s and 1990s have shifted to "farmers of mixed sheep." Moreover, dairy farmers who promoted multiple operations with the introduction of beef cattle from the 1980s and expanded by incorporating other farms have become "farmers of mixed bovids." Newly engaged farmers from other regions from the 1990s have focused on promoting the production of high-quality agricultural products and have become "farmers of small-scale multiple operations."

As previously seen, the trigger for agricultural transitions and management differentiation in Mézenc were policies and generational changes in farm households. Policies that promoted the selection of small-scale farm households, farmland accumulation to large-scale farm households, specialization of management, and multiple operations divided dairy farmers with other farming operations into three types: dairy farmers, beef cattle farmers, and farmers of multiple operations. Meanwhile, the decision making of the farmers after the retirement of their parent's generation has involved significant management changes in each farm household. Each farm householder who has recently taken over farmland as a result of a generational change has emphasized the management policy and strategies they aspire to, as well as take into consideration the change in agricultural policies and their impact on farm management.

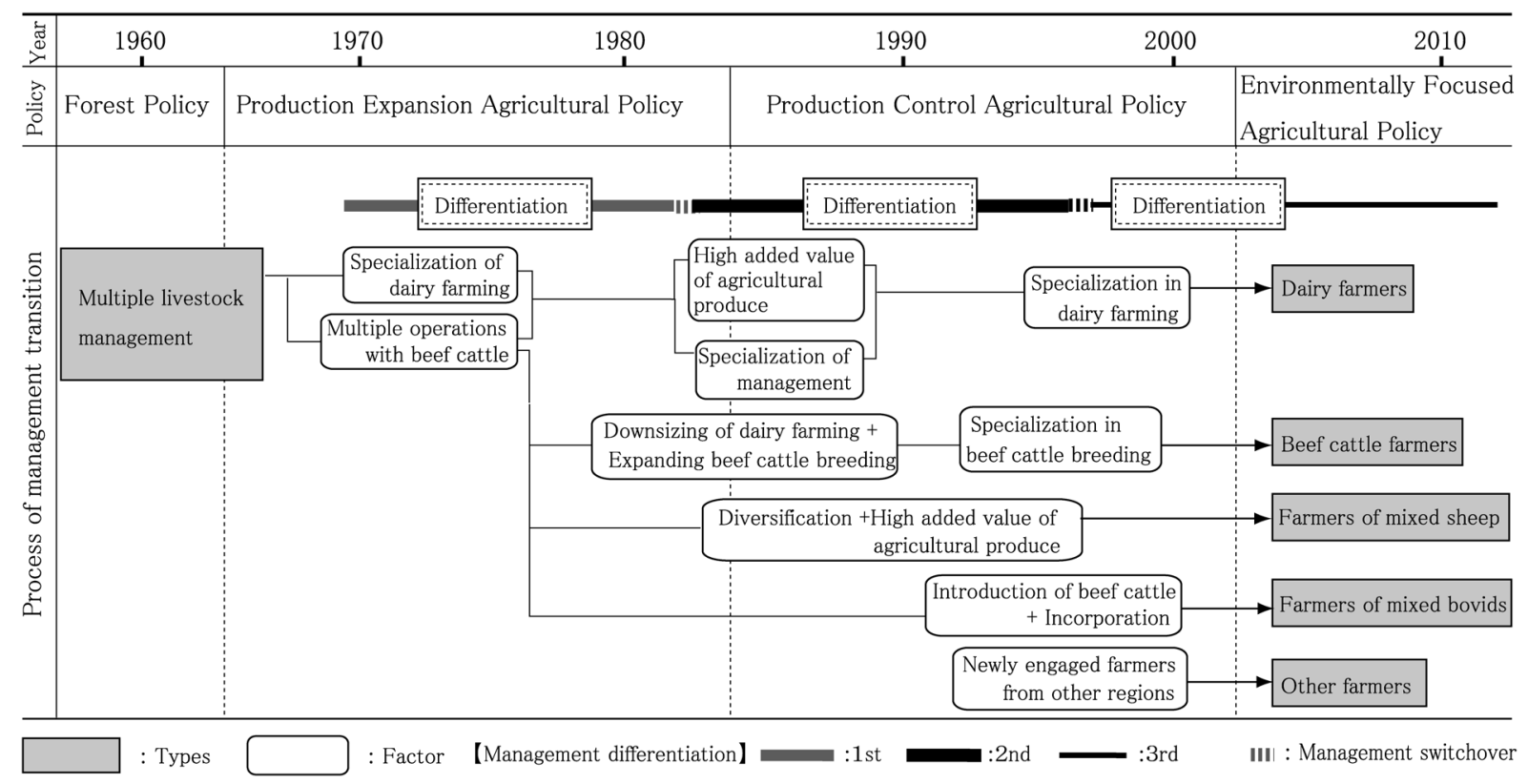

Figure 4. Process of management transition of farm households in Mézenc.

Source: Author's interview. 


\section{Changes in Mountain Farming under the EU Common Agricultural Policy}

\section{Farm economy policy}

In farm management in Mézenc, income from subsidies is essential for operation, and mountainous farm households have increased their degree of dependence on subsidies since the 1990s. These subsidies are composed of multiple categories, which are classified by the kind of livestock and farm management type. As shown in Figure 5, this study classifies the subsidies seen in the farm economy of Mézenc into five types: "single payment," "payment to less favoured areas," "payment for the environment," "payment for the number of livestock," and "other." Payment of these five subsidies requires meeting cross-compliance, which is a CAP payment requirement. In case of failure of cross-compliance, a penalty fee is imposed or the subsidy is reduced.

The largest common agriculture policy subsidy payment each farm household receives is the "Single Payment (DPU: Droit Paiment Unique)," which accounts for $38.7 \%$ of all subsidies received by the investigated farm households. The second largest payment is "the payment to the less favoured areas (ICHN: L'Indemnité Compensatoire de Handicaps Naturels)," which accounts for approximately $26.9 \%$ of subsidies received. The next important agricultural subsidy is the "Payment for the Environment (MAE: Les Mesures Agro-environnementales) ${ }^{7}$," which accounts for $17.9 \%$ of total subsidy payments. Payment for the environment has taken over the financial incentive of grasslands, which was started in 1993 as a unique French environmental policy, and farm households in Mézenc still recognize it as a financial incentive to maintain grasslands.

On the other hand, the subsidy connected to production (recoupling) involves payment for the number of livestock. The target of this policy are sheep, goats, and female cows for breeding; this benefits sheep and goat husbandries, where a high income cannot be expected, and beef meat production, which is in high demand inside and outside France (and which stands in contrast to raw milk production, whose production volume is saturated). These payments are directly connected to production volume; thus, the greater the number of livestock, the more the money farmers receive. These policies give preferential treatment to sheep and beef cattle husbandries.

Subsidies classified as "other" include recoupling-related grants for mountainous husbandry, rotation cropping, and slaughtering; however, the amount paid is not substantial.

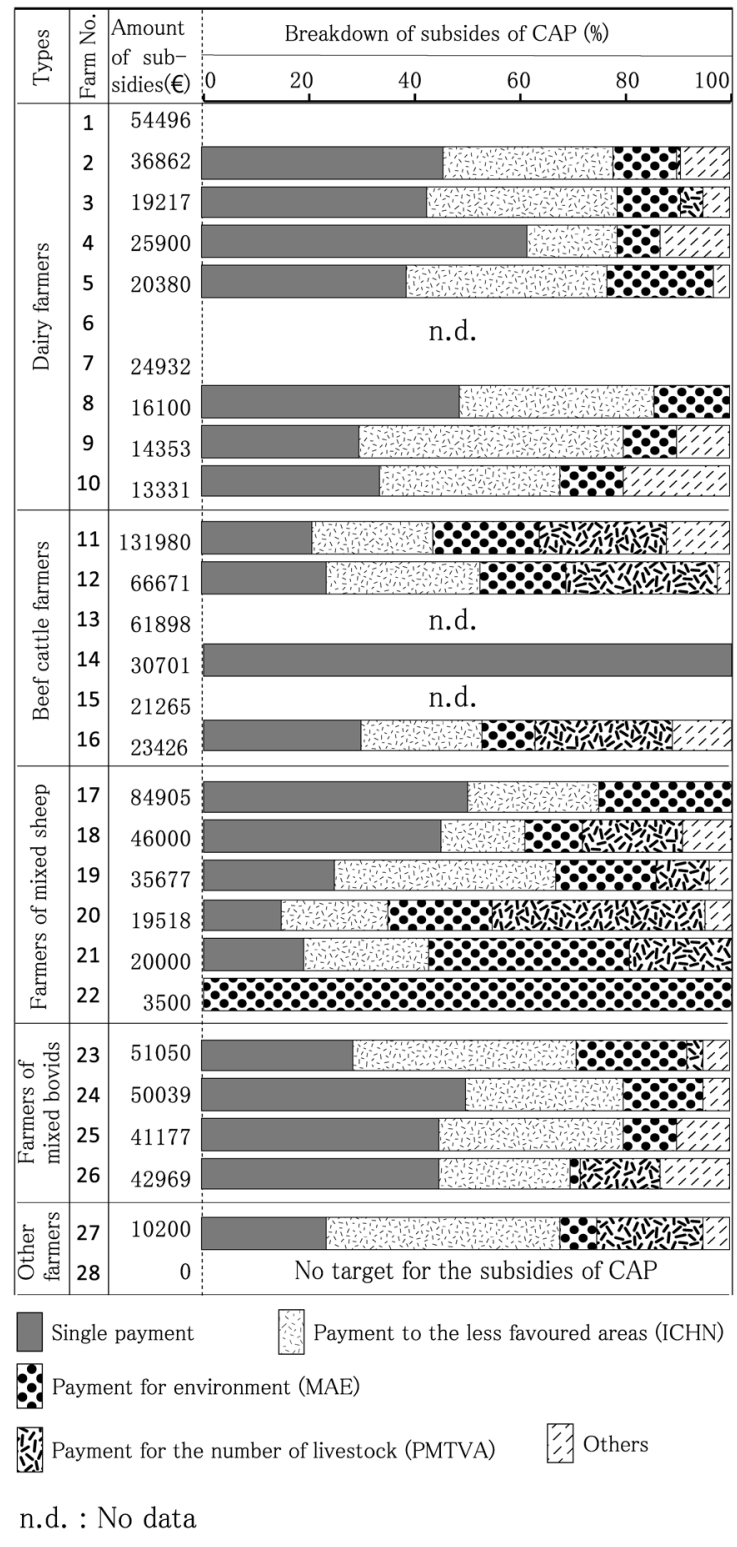

Figure 5. Breakdown of subsides of common agricultural policy in farm households in Mézenc (2011).

Source: Author's interview and account books of farmers.

Table 4 shows the characteristics of the subsidy composition of farm households by farm management type. In terms of the total money received, the average amount per hectare of farmland for beef cattle farmers is the most, $€ 591$, and that of dairy farmers is the least, $€ 346$. Farmers of mixed sheep received $€ 413$, which is the second most following beef cattle farmers; farmers of mixed bovids received $€ 363$. The large amounts of subsidies of farmers of beef cattle and mixed sheep are attributed to the payment for the number of livestock. The average payment for the number of livestock accounts for $19.6 \%$ of total received subsidies for beef cattle farmers and $14.7 \%$ for mixed sheep farmers, who benefit from preferential political measures through the subsidies. In contrast, since dairy farmers cannot be the main targets to 
Table 4. Average received subsidy per ha of farmland by type of agriculture of case farm households in Mézenc (2011) (unit=\%)

\begin{tabular}{|c|c|c|c|c|c|c|}
\hline Types & $\begin{array}{l}\text { Single } \\
\text { payment }\end{array}$ & $\mathrm{ICHN}$ & MAE & PMTVA & Others & $\begin{array}{c}\text { Average amount } \\
(€ / \mathrm{ha})\end{array}$ \\
\hline Dairy farmers & 43.3 & 34.9 & 12.6 & 0.7 & 8.5 & 346 \\
\hline Beef cattle farmers & 43.7 & 18.6 & 11.5 & 19.6 & 6.6 & 591 \\
\hline Farmers of mixed sheep & 25.7 & 21.2 & 35.5 & 14.7 & 2.9 & 413 \\
\hline Farmers of mixed bovids & 42.3 & 33.0 & 12.0 & 4.5 & 8.2 & 363 \\
\hline Other farmers & 24.0 & 44.0 & 7.0 & 20.0 & 5.0 & - \\
\hline Average (\%) & 38.7 & 26.9 & 17.9 & 9.9 & 6.6 & 429 \\
\hline
\end{tabular}

ICHN: L'Indemnité Compensatoire de Handicaps Naturels.

MAE: Les Mesures Agro-environnementales.

PMTVA: La Prime au Maintien du Troupeau Vaches Allaitantes.

Source: Author's interview and account books of farmers.

receive payment based on their number of livestock, they largely depend on a single payment (43.3\%) and payment to less favoured areas (34.9\%).

Payments for the environment account for $35.5 \%$ of the total received subsidies of farmers of mixed sheep, which is particularly high. They supplement the low income from sheep meat production with the application of environmentally oriented agriculture and high value-added types of products, and make efforts to meet the requirements to receive subsidies. Meanwhile, there is no large difference in the proportion of payments between dairy farmers and farmers of mixed bovids, as it is understood that subsidies for dairy husbandry are standardized. In terms of the received amount being based on farmland acreage, there is a big difference between farm households of beef cattle farmers and farmers of mixed sheep, but little difference between farm households of dairy farmers and farmers of mixed bovids. This indicates that the management scale of beef cattle farmers largely differs, and it is possible that organic agriculture or environmentally oriented farming methods result in different subsidy amounts.

\section{Relationship between farm management and policy}

In the management transition of farm households in Mézenc, three political measures by the CAP were important. The first was the milk quota system in 1984, which had a major impact on core farming and dairy husbandry, and was the first trigger for management differentiation between dairy cattle farmers and other operations. The second was the introduction of the direct payment system in 1992. This system accounts for the largest part of current farm households' subsidy income in Mézenc, and increased farmers' dependence on subsidies. The third was the introduction of cross-compliance in 2003. Cross- compliance is a requirement for receiving a subsidy from the direct payment system. As for the three above political measures, a hearing investigation on their impact on management and the opinions of each household was made; the replies are given in Table 5.

Those who experienced an "increase in raw milk production" were mainly dairy farmers (farm households 2 , $4,9,10$ ) and farmers of mixed bovids (farm households $23,26)$, and it can be understood that the large allocation of the milk quota enabled the continuation of dairy husbandry. Meanwhile, excluding farm household 8, a "decrease or stagnation in raw milk production" was reported by beef cattle farmers (farm households 11, 13, $15,16)$ and farmers of mixed sheep (farm households 18 , 19, 21). Policy has significantly affected specialization in beef cattle operation, sheep husbandry, and the promotion of multiple operations. In addition, "management diversification" and "discontinuation of grain cultivation" are recognized as measures taken by dairy farmers in response to policies (farm households 6-8), and they are considered essential management strategies for the continuation of dairy husbandry. On the other hand, some managements have stated that these policies have had "no major impact" on each management type, although the number of such respondents is small (farm households $9,12,17,20,23)$ and it is understood that there is a management difference in Mézenc. As for the reasons, it can be pointed out that the milk quota system focused on reducing the production of large-scale farm households in flat areas and in Mézenc, a mountainous region, and it is considered that a positive impact such as an increase in production volume also occurred because of preferential political treatment.

Most participants replied that the abolition of price supports and the introduction of direct payments in 1992 
Table 5. Relation between farm households and EU common agricultural policy in Mézenc

\begin{tabular}{|c|c|c|c|c|c|c|}
\hline Policy & Contents & Dairy farmers & $\begin{array}{l}\text { Beef cattle } \\
\text { farmers }\end{array}$ & $\begin{array}{l}\text { Farmers of } \\
\text { mixed sheep }\end{array}$ & $\begin{array}{l}\text { Farmers of } \\
\text { mixed bovids }\end{array}$ & Other farmers \\
\hline \multirow{7}{*}{ (1) Milk Quota System } & $\begin{array}{l}\text { (0) Increase in raw milk produc- } \\
\text { tion }\end{array}$ & $2 \cdot 4 \cdot 9 \cdot 10$ & & & $23 \cdot 26$ & \\
\hline & $\begin{array}{l}\text { A Decrease or stagnation in raw } \\
\text { milk production }\end{array}$ & 8 & $11 \cdot 13 \cdot 15 \cdot 16$ & $18 \cdot 19 \cdot 21$ & & \\
\hline & $\begin{array}{l}\boldsymbol{\Delta} \text { Obligation of beef cattle } \\
\text { breeding }\end{array}$ & 9 & & & & \\
\hline & $\begin{array}{l}\text { Introducing beef cattle } \\
\text { breeding }\end{array}$ & & $11 \cdot 13 \cdot 14 \cdot 16$ & & 25 & \\
\hline & - Management diversification & $7 \cdot 8$ & & 19 & & \\
\hline & No major impact & 9 & 12 & $17 \cdot 20$ & 23 & \\
\hline & $\begin{array}{l}\text { Discontinuation of grain } \\
\text { cultivation }\end{array}$ & 6 & & & & \\
\hline \multirow{2}{*}{ (2)* } & (c) Increase in subsidy & $4 \cdot 9$ & & & 25 & \\
\hline & No major impact & $4 \cdot 7$ & $11 \cdot 14$ & 18 & $23 \cdot 24$ & \\
\hline \multirow{9}{*}{$\begin{array}{l}\text { (3) Introduction of } \\
\text { Cross-Compliance }\end{array}$} & (a) Consider favorably & $2 \cdot 4$ & & 20 & 23 & \\
\hline & $\boldsymbol{\Delta}$ Too much paperwork & $3 \cdot 8$ & & & $25 \cdot 26$ & \\
\hline & $\begin{array}{l}\text { A Co mplaint about the regula- } \\
\text { tions of the policies }\end{array}$ & $2 \cdot 3 \cdot 7 \cdot 9 \cdot 10$ & $12 \cdot 16$ & & & \\
\hline & $\begin{array}{l}\text { A Decrease in motivation for } \\
\text { farming }\end{array}$ & $7 \cdot 10$ & 12 & & & \\
\hline & $\boldsymbol{\Delta}$ Increase of farmwork & 8.9 & 13 & 19 & 24 & \\
\hline & $\begin{array}{l}\text { A Complaints about no target } \\
\text { for CAP }\end{array}$ & & 14 & 22 & & $27 \cdot 28$ \\
\hline & $\boldsymbol{\Delta}$ Too difficult to comply items & & & & 24 & \\
\hline & $\begin{array}{l}\text { Improvement of manage- } \\
\text { ment }\end{array}$ & & & $18 \cdot 21$ & 23 & \\
\hline & No major impact & 5 & 13 & & 25 & \\
\hline
\end{tabular}

*: Introducing direct payment (1)1984 (2)1992 (3) 2003 .

(०): Positive impacts, $\mathbf{\Delta}$ : Negative impacts, $\mathbf{\square}$ : Other impacts.

Source: Author's interview.

had "no major impact" (farm households 4, 7, 11, 14, $18,23,24)$; furthermore, there was a positive impact seen, an "increase in subsidy." These farmers feel that despite large-scale system reform, in mountainous farm management, agricultural income was maintained, and the farmers enjoyed the benefits of an increased subsidy. However, as the introduction and expansion of the direct payment system gradually advanced, it is possible that individual farmers could not understand the real impact on their operations. No farm households reported a negative impact, which indicated that there were few negative opinions held by the farm households of Mézenc. Furthermore, reform of the CAP in 1992 focused on largescale acreage reduction of grain cultivation and extensive farmland set aside by obligation, and thus it can be considered that a major intervention in the management of mountainous dairy husbandry was not made.

Meanwhile, with regard to cross-compliance, which was introduced as a CAP requirement in 2003 for receiving a subsidy, unlike the two above measures, a great number of negative impacts can be identified. Of all the negative impacts, the greater workload and increased working hours, including "too much paperwork to fill out" (farm households 3, 8, 25, 26), was confirmed as a major complaint. As for the causes of this workload increase, it can be said that the hours of paperwork are compressing those of farming, since farmers must specify, in detail, their appropriate management, farming plan, and status of operation implementation for all owned farmland. In their opinion, such work causes a "decrease in motivation for farming operation" (farm households $7,10,12)$ where meeting requirements to receive a sub- 
sidy seems to become a purpose of farming is concerned. There were other opinions, such as, "if there is time to do paperwork, we should utilize it for farming" (farm households 8,21 ). It can also be understood that the balance of agricultural production activity and environmental control activity results in increased pressure and burden on farm households.

Moreover, concerning complaints about policies and the federal and local governments as implementing entities, farm households $2,3,7,9,10,12$, and 16 had particular complaints concerning policy regulations. In particular, many dairy farmers, whose production volume is controlled, complained about the entities that implement environmental regulations. In addition, as a complaint about the policy itself, "no target for the subsidy" was a problem identified by farm households 14, 22, 27, and 28 , and it can be understood that support for smallscale farm households, which are not eligible to receive a subsidy, is insufficient. There are a few negative opinions about the operation of management, as follows: "it is difficult to comply with items" on payment for the environment (farm household 24) and "the subsidy amount was reduced" by the introduction of the system (farm household 18).

However, a few farm households had favorable opinions on the environmentally oriented agricultural method and landscape conservation in payment for environment in terms of a sense of nations' common property control (farm households 2, 4, 20, 23). There are some flexible farm households: the increase in workload by the introduction of the system is handled through an "improvement of operation or management" (farm households $18,21,23)$. On the other hand, farm households who indicated "no major change" (farm households 5, 13, 25) consider that only the workload has increased, and make neither positive nor negative comments.

\section{Conclusion}

Mountainous regions in France have experienced significant change since the establishment of the CAP. Growth of agricultural policy surrounding Mézenc can be divided into three types: structural policy, production intervention policy, and multifunctional agricultural policy. Structural policy was first applied to land consolidation from 1960 to 1970, and included IVD, the GAEC corporation system, and the promotion of young farmers. IVD, the promotion of young farmers, and the establishment of the GAEC corporation system resulted in the selection and removal of small-scale elderly farm households, the scale expansion of management, an increase in corporation management, the differentiation between traditional dairy husbandry and other operations, and a specialization in dairy husbandry in Mézenc. Moreover, land consolidation, farmland development, and the rapid introduction of agricultural machinery changed the mosaiclike rural landscape, which had been occupied by various crops, including potatoes, wheat, barley, and rye, to expansive grasslands and led to larger farmland lots. While such structural policies contributed to the expansion of scale, the introduction of agricultural machinery, and an increase in corporations in Mézenc, they also led to the selection and removal of small-scale farm households and a decline of regionally traditional livestock breeds such as Aubrac and Salers.

Policy to control production for the supply of surplus agricultural produce caused by structural policy has been implemented since the 1980s. Such policies include the milk quota system, the compensation for female sheep and female cattle for breeding, and the direct payment system; these can be considered policies of intervention in the production of French agriculture. In particular, the milk quota system changed the traditional dairy farmers in Mézenc. However, the impact of the milk quota system differs; in the western area, where the altitude is low, specialization in dairy husbandry and scale expansion have advanced, while in eastern Mézenc, which is surrounded by mountains and is at a higher altitude, there has been an abandonment of dairy husbandry and a shift to beef husbandry. Compensation for female sheep and cattle for breeding increased the numbers of beef cattle farmers, farmers of mixed sheep, and diversified farm management types in Mézenc. Above all, in the east, where crop farming has declined remarkably, beef cattle and sheep husbandry has increased, and these management types have increased the dependence on subsidy income by the direct payment system compared to other types.

The policies that have influenced farm management in Mézenc since the 1990s have mainly been related to multifunctional agriculture. In particular, the incentive to maintain grassland and payment for the environment promoted high-density livestock and extensive farmland use and became triggers for shifting the role of agriculture from a production function to an environmental one. Policies emphasizing environmental aspects have been reinforced by cross-compliance obligations, and farm management groups in Mézenc, which highly depend on subsidies, have been restricted by environmental controls in various ways. In particular, a large amount of detailed cross-compliance paperwork must be filled out; this is a 
huge burden. There exists a perception gap between such regional farm management groups and environmental policies, which indicates that policymakers tend to have a poor grasp of the actual conditions of regional farm management.

The relationship between mountainous agriculture and policies in France until the early 1960s was developed homogenously through protective forestry policy by the government; in mountainous regions, traditional mountainous husbandry focusing on dairy operation was mainly implemented. The establishment of the EC and the start of the CAP drastically changed traditional agriculture in Mézenc, where production and distribution had been completed locally.

The main policy support for mountainous agriculture during the production-oriented agricultural policy period was indirect, with price support and export subsidies by the nation and the EC. In addition, land development for mountainous regions, which began in the 1970s, did not solve the fundamental problems of declining mountainous agriculture. However, structural policy aimed at productivity improvement changed the concept of localized production and distribution, which led to the weakening of connections to regional factors, including trading with major companies outside the region and increases in nonregional breeds.

The major turning point for mountainous agriculture in France was the start of the agricultural policy period of production control in the early 1990s. As policies were developed from production expansion to production control, the loss of agricultural income in France was covered by agricultural subsidies. Mountainous agriculture, whose productivity is lower than that of flat areas, expanded the area considered less favoured, and has been protected by various entities, including pays, prefectures, regions, nations, and the EU.

The enhancement of protective policies for mountainous agriculture in France has been based on the promotion of local support, such as regions, pays, and prefectures, by the policy of decentralization. Localization of policy support is connected to the reevaluation of regional traditions, to sources such as the promotion of organic agriculture and brand strategy in Mézenc, or to newly created agricultural produce and regional factors that waned during the period of production-oriented agricultural policy, but which have been emphasized again. Moreover, collaboration with the regions surrounding Mézenc and the restructuring of relationships to regional markets has supported the distribution and production of local agricultural produce. The value of the local agricul- tural produce reflects the good image of the mountainous regions held by urban French consumers.

During the period of production control-oriented agricultural policy, mountainous agriculture was subjected to many regulations because of subsidy policies by various entities. In addition, the advantages of multifunctional agriculture and its environmental aspect are expected to be significant compared to those of flat areas, which focus on production functions. Therefore, rural public interest in social meanings were utilized as a plea for subsidies for mountainous regions, as all the farmland, landscape, livestock, and agricultural products that mountainous farm households control have been increasingly supervised by the French national government. In this way, the changes in the mountainous regions in France have brought with them policy development on a macro level as well as environmental change, and it can be said that the management transition of farm households in Mézenc resulted from such regional influences.

The net production profit of the mountainous regions in France is the lowest of the less favoured areas, and farmers there are highly dependent on subsidies. Farming conditions are severe compared to flat regions, which feature more self-reliance and where more productive agriculture is implemented. Massif Central, the largest mountainous region in France, prominently displays the common characteristics of mountainous regions, as extensive husbandry is dominant and the proportion of subsidies accounting for agricultural income is high.

As mentioned in this study, it is necessary to support the management income of farm households in mountainous regions with multiple subsidy policies by introducing subsidies through the environment, payments for less favoured areas, and payments for specific crops or livestock. The protection of mountainous agriculture is closely related to the population outflow of mountain villages, landscape conservation, and the inheritance of culture, and is important to prevent the decline of mountainous regions and rural villages.

\section{Acknowledgements}

I received a great deal of cooperation from owners of farms and their family members including Ms. Elisabeth Chalindar, and villagers of Monastier-sur-Gazeille. I would like to express my sincere gratitude to them. I also received a great deal of guidance from professors of the School of Life and Environmental Sciences at the University of Tsukuba including Prof. Akira Tabayashi, Prof. Akira Tezuka, and Prof. Philippe Pelletier of National 
University of Lyon 2-Lumière. Finally, I would like to thank everyone who aided this study. A summary of this paper was presented at the Human Geographical Society of Japan in November 2012 (Ritsumeikan University). This work was supported by part of a series of singleyear grants in 2000-2012 (Grant-in-Aid for JSPS Fellows: Grant Numbers: 22·291).

\section{Notes}

1. The author analyzed the selections and actions that mountainous farm households take to sustain and develop farm management; the selection of the kinds of livestock and sales channels for produce, the breakdown of income, the farmland, the laborforce, and the promotion of high value-added types of produce (Ichikawa 2012). The management of mountainous farm households which are analyzed in this article (Farm nos. 1-28) are identical with the author's previous study.

2. As a subsidy to promote a specific farmer, a payment for the number of livestock directly connected to production volume can be raised. Payment for the number of livestock in Mézenc particularly targets sheep, goat, and beef cattle. According to the hearing investigation, the subsidy amount of single payment for sheep has been increased since 2010 and its producers have been protected.

3. CTE, a French sustainable agriculture contract, and the promotion of organic agriculture in Auvergne have contributed to the production of high value-added types of mountainous agricultural produce and promoted the acquisition of geographical appellations for beef and grain, the incorporation of organic agriculture, and an increase in new farmers.

4. Cross-compliance refers to the requirement for farming practices to meet certain standards. These apply if a farmer receives direct payments under CAP support schemes or through certain Rural Develcopment Schemes. This includes the Single Payment Scheme (SPS)-the EU's main agricultural subsidy scheme.

5. Agenda 2000 explicitly established economic, social, and environmental goals within a new reformulated set of objectives for the CAP consistent with the requirements of the Amsterdam Treaty. Cross-compliance, firstly introduced on a voluntary basis in the Agenda 2000, was further developed in the 2003 CAP reform.

6. In the French census of agriculture, there exist two management categories: "professional management" to be developed and "nonprofessional management". According to the census, professional management is defined as the one whose economic scale unit is over 8UDE (Unité de Dimension Eropéenne, €9,600) and annual labor force unit is over 0.75 of UTA (Unité de Travail Annuel). IUTA is the equivalent of one full time farmer (over 2300 labor hours a year).

7. At the hearing investigation on site, most of the farm households did not know the amount of payment for environment (MAE) since it is recognized as incentive for grassland (PHAE). Most Cross-Compliance, which is a payment for environment, is also the one for incentive for grassland in Mézenc.

\section{References}

Bazin, G. 2003. La PAC contre la multifunctionnalité. Économie Rural 273-274: 236-242. (F)

Broggio, C. 1992. Les enjeux d'une politique montagne pour l'Europe. Revue de Géographie Alpine 80(4): 26-39. (F)
Broggio, C. 2002. La politique de la montagne en France: Représentations, discours et montagne. La Découverte 107: 147-158. (F)

Charvet, J. P. 2009. Les agricultures de l'Union Européenne dans la mondialisaton. L'Information Géographique 73: 49-64. (F)

Chevallier, M. 1989. La Loi Montagne et sa mise en œuvre (1981-1988). Annales de Géographie 545: 84-91. (F)

Clark, J. 2006. The institutional limits to multifunctional agriculture: Subnational governance and regional system of innovation. Environment and Planning C 24: 331-349.

Devienne, S., Bazin, G. and Charvet, J. P. 2005. Politique agricole et agriculture aux États-Unis: Évolution et enjeux actuels. Annales de Géographie 641: 3-26. (F)

Féminier, B. 2000. Retour sur le XIX siécle. In 100 ans d'agriculture en Haut-Loire de 1900 à 2000, ed. Chambre d'agriculture de Haut-Loire, 9-12. Le-Puy-en-Velay: L'imprimerie Jeanne d'Arc. (F)

Frasse, M. 2000. Les grandes évolution de l'agriculture. In 100 ans d'agriculture en Haut-Loire de 1900 à 2000, ed. Chambre d'agriculture de Haut-Loire, 13-48. Le-Puy-en-Velay: L'imprimerie Jeanne d'Arc. (F)

Gerbaux, F. 1994. La montagne en politique. L'Harmattan: Condésur-Noireau. (F)

Huyghe, C. 2008. La multifunctionnalité des prairies en France: Les fonctions de production. Chaiers Agricultures 17: 427-435. (F)

Ichikawa, Y. 2012. Management strategies of mountain farmers in the less favoured areas of France: A case study of Pays du Mézenc, Massif Central. Journal of Geography (Chigaku Zasshi) 121: 1010-1029. (JE)

Ishii, K. 1998. Direct income payments for low-intensity farming in French less favoured areas. Quarterly Journal of Agricultural Economics 52(1): 1-50. (J)

Korenaga, T. 1998. Mountain Agriculture in France. Tokyo: Nobunkyo. (J)

Loyat, J. and Petit, Y. 2008. La politique agricole commune (PAC): Une politique en mutation. Condé-sur-Noireau: La documentation Française. (F)

Martin, S. and Novarina, G. 1991. De la congestion agricole à la cogestion rurale: Lexemple de la politique de la montagne. Économie Rural 201: 33-36. (F)

Massot-Marti, A. 2003. La paradigm multifunctionnel: Outil et arme dans la renégociation de la PAC. Économie Rural 273-274: 30-44. (F)

McCarthy, J. 2005. Rural geography: Multifunctional rural geographies-Reactionary or radical. Progress in Human Geography 29: 773-782.

Perraud, D. 2003. Les ambiguïtés de la multifonctionnalité de l'agriculture. Économie Rural 273-274: 45-60. (F)

Potter, C. and Tilzey, M. 2005. Agricultural policy discourses in the European post-Fordist transition: Neoliberalism, neomercantilism and multifunctionality. Progress in Human Geography 29: 581-600.

Râmniceanu, I. and Ackrill, R. 2007. EU rural development policy in the new member states: Promoting multifunctionality. Journal of Rural Studies 23: 416-429.

Sakuyama, T. 2006. International negotiations over the multifunctionality of agriculture. Tokyo: Tsukubashobo. (J)

Servolin, C. 1989. L'agriculture moderne. Paris: Le Seuile. (F) 
Wilson, G. A. 2009. The spatiality of multifunctional agriculture: A human geography perspective. Geoforum 40: 269-280.
(F) written in French

(J) written in Japanese

(JE) written in Japanese with English abstract 